\title{
IMPLEMENTASI A PEMBIAYAAN MURABAHAH PADA BAITUL MAL WAT TAMWIL (BMT) KOTA PEKANBARU
}

\section{IMPLEMENTATION OF MURABAHAH FINANCE IN BAITUL MAL WAT TAMWIL (BMT) KOTA PEKANBARU PEKANBARU CITY}

\author{
Ficha Melina ${ }^{1}$, Marina Zulfa ${ }^{2}$ \\ Universitas Islam Riau ${ }^{1,2}$ \\ fichamelina@fis.uir.ac.id ${ }^{1}$
}

\begin{abstract}
The rise of banking development using the principles of sharia, or better known as sharia banks or sharia microfinance institutions (LKMS) in Indonesia, is no longer a foreign matter. Research Objectives To find out how the implementation of Murabahah financing products in the BMT city of Pekanbaru, To find out whether the implementation of the Murabahah BMT contract in Pekanbaru is in accordance with Islamic principles. The method used is the total sampling method in which the population and sample numbered 22 people from the leadership of BMT or the Pekanbaru BMT financing department. Based on the results of this study that the Implementation of Murabahah Financing Products at BMT Pekanbaru City in the form of murabaha Objects, Cost and Profit, Cost, Advance, Purchase and Delivery of Goods, Resilient Payment, are very much in demand by customers and the public. It can be seen that there are many BMTs in the city of Pekanbaru that apply murabahah financing products that are principled to Muamalah in Islam. So that customers / communities are more interested in murabaha financing products than other products, and this financing is in accordance with Islamic Sharia principles.
\end{abstract}

Keywords: Implementation, Financing, Murabahah, BMT Pekanbaru City

\begin{abstract}
ABSTRAK
Maraknya perkembangan perbankan dengan menggunakan prinsip syariah atau lebih dikenal dengan nama bank syariah ataupun lembaga keuangan mikro syariah (LKMS) di Indonesia, bukan merupakan hal yang asing lagi. Tujuan penelitian Untuk mengetahui bagaimana implementasi produk pembiayaan Murabahah, untuk mengetahui apakah implementasi akad Murabahah sudah sesuai dengan prinsip-prinsip syariah. Metode yang digunakan adalah metode total sampling yang mana populasi dan sampel berjumlah 22 orang dari pimpinan BMT atau bagian pembiayaan BMT kota pekanbaru. Berdasarkan hasil penelitian ini bahwa Implementasi Produk Pembiayaan Murabahah pada BMT Kota Pekanbaru dalam bentuk Obyek murabahah, Harga Perolehan dan Keuntungan, Harga Perolehan, Uang Muka, Pembelian dan Penyerahan Barang, Pembayaran Tangguh, sangat diminati oleh nasabah dan masyarakat. Hal ini dapat diketahui banyaknya BMT di kota pekanbaru yang menerapkan produk pembiayaan murabahah yang berprinsip kepada Muamalah dalam Islam. Sehingga nasabah/masyarakat lebih tertarik dengan produk pembiayaan murabahah dari pada produk lainnya, serta pembiayaan ini sesuai dengan prinsip syariat islam.
\end{abstract}

Kata Kunci : Implementasi, Pembiayaan, Murabahah, BMT Kota Pekanbaru 


\section{PENDAHULUAN}

Perkembangan perbankan dengan menggunakan prinsip syariah atau lebih dikenal dengan nama bank syariah ataupun lembaga keuangan mikro syariah (LKMS) di Indonesia, bukan merupakan hal yang asing lagi. Faktor penting yang melatarbelakangi lahirnya bank syariah maupun lembaga keuangan mikro syariah adalah pelarangan riba secara tegas dalam Alquran. Riba adalah pengambilan tambahan, baik dalam transaksi jual beli maupun pinjam meminjam secara batil atau bertentangan dengan prinsip muamalah dalam Islam. Salah satu lembaga keuangan mikro syariah yang berbentuk koperasi adalah Baitul Mal WatTamwil (BMT) (Affandi, 2015).

BMT adalah lembaga keuangan syariah yang beroperasi menggunakan gabungan konsep "Baitul Tamwil dan Baitul Mal" dengan target operasionalnya fokus kepada sektor Usaha Kecil Menengah (UKM) (Thamrin \& Susilo, 2017). Konsep Baitul Tamwil (rumah pengembangan harta), melakukan kegiatan pengembangan usaha-usaha produktif dan investasi dalam meningkatkan kualitas ekonomi pengusaha mikro dan kecil dengan antara lain mendorong kegiatan menabung dan menunjang pembiayaan kegiatan ekonomi. Sedangkan konsep Baitul Mal (rumah harta), menerima titipan dana zakat, infak dan sedekah serta mengoptimalkan distribusinya sesuai dengan peraturan dan amanahnya (Azizah, 2015).

Kota Pekanbaru adalah ibu kota provinsi Riau yang mayoritas penduduknya beragama Islam dan berbudaya melayu dengan luas wilayah 8.915.016 KM2 dan jumlah penduduk 1,2 juta jiwa (2018) yang sebagian besar penduduknya bekerja di sector jasa dan perdagangan. Dalam beberapa tahun terakhir kota pekanbaru mengalami perkembangan yang pesat baik itu dari sektor pembangunan maupun sektor perekonomian. Sehingga ini menjadi potensi yang besar untuk perkembangan Baitul Mal Wat Tamwil (BMT) yang ada di Kota pekanbaru.

Tujuan yang ingin dicapai para penggagasnya tidak lain untuk menampung dana masyarakat dan menyalurkannya kembali kepada masyarakat terutama pengusahapengusaha semisal pengusaha muslim yang membutuhkan bantuan modal untuk pengembangan bisnisnya dalam bentuk pemberian fasilitas pembiayaan kepada para nasabah berdasarkan prinsip syariah, seperti murabahah, mudharabah, musyarakah, qardh dan lain-lain.

Salah satu produk di Baitul Mal Wat Tamwil (BMT) adalah produk akad murabahah. Murabahah merupakan kontrak jual-beli dimana bank bertindak sebagai penjual sementara nasabah sebagai pembeli. Harga jual adalah harga beli bank ditambah keuntungan. Walaupun akad murabahah ini sering digunakan, namun sebagian masyarakat belum mengerti tentang implementasi akad ini. Sehingga banyak anggapan bahwa praktik pada lembaga keuangan syariah tidak berbeda jauh dengan lembaga keuangan konvensional yang terlebih dahulu dikenal oleh masyarakat luas.

Menurut Fatwa Dewan Syariah Nasional MUI No. 04/DSNMUI/IV/2000 tentang murabahah disebutkan bahwa bank (BMT) harus membeli terlebih dahulu aset yang dipesan oleh nasabah secara sah dan kemudian menawarkan aset tersebut kepada nasabah. Syarat-syarat benda yang menjadi objek akad dalam akad murabahah, barang yang diperjual belikan secara prinsip harus sudah menjadi milik bank (BMT). Tidak sah 
menjual barang-barang yang baru akan menjadi miliknya

Mudharabah merupakan akad kerjasama usaha antara dua pihak dimana pihak pertama (pemilik dana) menyediakan seluruh dana; sedangkan pihak kedua (pengelola dana) bertindak selaku pengelola, dan keuntungan usaha dibagi diantara mereka sesuai kesepakatan sedangkan kerugian finansialnya hanya ditanggug oleh pengelola dana. Fatwa DSN (Dewan Syariah Nasional) menjelaskan bahwa yang dimaksud dengan murabahah adalah menjual suatu barang dengan menegaskan harga belinya kepadapembeli dan pembeli membayarnya dengan harga yang lebih sebagai laba. Sedangkan dalam PSAK 59 tentang Akuntansi Perbankan Syariah paragraf 52 dijelaskan bahwa murabahah adalah akad jual beli barang dengan menyatakan harga perolehan dan keuntungan (margin) yang disepakati oleh penjual dan pembeli (Iltiham, 2017).

Penelitian ini mengadopsi beberapa penelitian terdahulu oleh Hasanah et al., (2015) dimana penelitiannya fokus terhadap pengelolaan manajemen resiko akad mudharabah di BTM-UGT Wonogiri. Selanjutnya penelitian oleh Sagara \& Pratama (2016) dimana akad pembiayaan murabahah di BMT Khaifa Kebon Gedang Bandung cukup signifikan dalam membantu usaha mereka yang sebagian besar sektor usaha informal. Febrian \& Mardian (2017) juga meneliti tentang penerapan PSAK 59 dalam pembiayaan murabahah di salah satu BMT di Jawa Barat yang hasilnya tidak semua transaksi murabahah menjalankan penerapan PSAK ini.

Berbeda dengan penelitianpenelitian di atas, penelitian ini membahas mengenai permasalahan- permasalahan yang di hadapi oleh BMT yang ada di Kota Pekanbaru. Penelitian ini oleh lebih terfokus pada bagaimana penerapan atau implementasi produk pembiayaan Murabaha di BMT-BMT yang ada di Kota Pekanbaru.

\section{METODE PENELITIAN}

Penelitian ini termasuk jenis penelitian lapangan (field research) dengan pendekatan deskriptif kualitatif untuk memaparkan data-data yang didapat di lapangan kemudian di implementasikan dan mendapatkan kesimpulan dari penelitian ini. Penelitian ini digunakan untuk mengambillokasi Baitul Mal Wa tam wil (BMT) di Kota Pekanbaru dalam memilih produk-produk syariah yang cukup diminati nasabah atau masyarakat. Sehingga penulis tertarik untuk meneliti aplikasi murabahah pada BMT Kota Pekanbaru. Adapun populasi dan sampel dalam penelitian ini adalah 1 orang Pimpinan BMT Kota Pekanbaru, dan 1 orang karyawan/I BMT bagian Pembiayaan di BMT Kota Pekanbaru disetiap BMT yang ada di Kota Pekanbaru. Jadi jumlah keselurahan yaitu berjumlah 22 orang dengan menggunakan metode total sampling. Metode pengumpulan data penelitian ini adalah Orservasi, Wawancara, Kepustakaan, Dokumentasi.

\section{HASIL DAN PEMBAHASAN}

Hasil penelitian yang dilakukan merupakan penelitian lapangan, oleh sebab itu data yang disajikan dalam bab ini adalah data yang dikumpulkan dari lapangan. Adapun teknik pengumpulan data yang digunakan untuk memperoleh data tersebut adalah dengan menggunakan observasi, wawancara dan dokumentasi. Hasil wawancara ini akan menunjukkan bahwa implementasi produk pembiayaan murabahah yang 
dilakukan pada Baitul Mal Wat Tamwil (BMT) Kota Pekanbaru.

Wawancara ini dilakukan dengan Pimpinan BMT Kota Pekanbaru, dan 1 orang karyawan/I BMT bagian Pembiayaan di BMT Kota Pekanbaru. Kemudian data disajikan dalam bentuk uraian singkat kedalam masing-masing kategori dan disimpulkan secara kualitatif. Adapun penyajian dari hasil pengumpulan data berdasarkan beberapa dimensi dalam penelitian ini yang dijabarkan sebagai berikut :

\section{Obyek Murabahah}

Obyek murabahah adalah perjanjian jual-beli antara BMT dengan Nasabah. BMT membeli barang yang diperlukan nasabah kemudian menjualnya kepada nasabah yang bersangkutan sebesar harga perolehan ditambah dengan margin keuntugan yang disepakati antara BMT dan Nasabah (Iltiham, 2017).

Dari hasil observasi penulis menunjukkan bahwa hasil wawancara tersebut sesuai dengan kondisi yang ada dilapangan yang menjelaskan bahwa obyek murabahah diterapkan sejak berdirinya BMT dan masyarakat lebih tertarik menggunakan akad murabahah dibandingkan akad lainnya karena akad murabahah merupakan perjanjian jual beli yang mempermudah masyarakat membeli produk secara cicilan berdasarkan prinsip syariah serta mempermudah membuat laporan keuangan. Berdasarkan temuan diatas penulis berkesimpulan bahwa BMT Kota Pekanbaru sudah menerapkan obyek produk pembiayaan murabahah sejak berdirinya usaha tersebut. Akan tetapi untuk meningkatkan ketertarikan masyarakat masih memiliki kekurangan. Oleh karena itu BMT Kota Pekanbaru harus lebih mempermudah masyarakat untuk membatu membeli produk yang dibutukan masyarakat, serta BMT harus lebih mempromosikan obyek murabahah yang berdasarkan prinsip syariah. Hasil analisis yang diperoleh melalui penelitian ini sesuai dengan penelitian-penelitian secara kualitatif yang telah dilakukan oleh peneliti sebelumnya seperti Suryani (2019) \& Affandi (2015) yang sama-sama menyatakan bahwa obyek murabahah yang ditawarkan BMT sangat diminati masyarakat karna tidak ada unsur ribanya dan tidaklah bertentangan dengan hukum dalam syariat islam.

\section{Harga Perolehan dan Keuntungan}

Harga perolehan adalah seluruh biaya yang dikeluarkan untuk memperoleh aset tetap tersebut mulai dari biaya pembelian hingga semua biaya yang timbul hingga aset tetap tersebut siap digunakan atau dioperasikan sedangkan keuntungan adalah suatu modal atau laba yang diperoleh dari investasi dalam surat berharga atau efek, seperti saham, obligasi atau dalam bidang properti dimana nilainya melebihi harga pembelian (Haryoso, 2017).

Dari hasil observasi penulis menunjukkan bahwa hasil wawancara tersebut sesuai dengan kondisi yang ada dilapangan yang menjelaskan bahwa harga perolehan dan keuntugan diterapkan sesuai kesepakatan antara BMT dan nasabah untuk menghindari riba dan keuntugan yang diterapkan BMT tidak ada ketetapannya tergantung kesapakatan di awal, dengan sistem pengukuran dengan nilai wajar yang diterima nasabah sesuai dengan prinsip syariah islam. Berdasarkan temuan diatas penulis berkesimpulan bahwa BMT Kota Pekanbaru belum penerapkan harga perolehan dan keuntugan produk pembiayaan murabahah dikarenakan untuk menghindari timbulnya riba dan 
penipuan dimana BMT menerapkannya sesuai kesepakatan bersama antara bmt dan nasabah diawal saat akad dilakukan.

Akan tetapi untuk menghidari riba maka BMT mengambil kesepakatan diawal dengan nasabah supaya tidak terjadi kesalahan setelah sah terima produk. Oleh karena itu BMT kota pekanbaru harus lebih memperhatikan dalam meningkatkan harga perolehan dan keuntugan supaya selalu terhindar dari riba, grarar, masyir dan slalu berprinsip berdasarkan syariah islam. Hasil analisis dan kesimpulan penulis menyatakan bahwa harga perolehan dan keuntungan yang diterapakan BMT Kota Pekanbaru sesuai dengan kesepakatan bersama antara pengelolah dan pembeli. Oleh karena itu BMT tidak menentukan harga perolehan dan keuntugan sendiri melainkan dengan kesepakatan besama, untuk menghindari timbulya riba. Probelamtika harga perolehan dan keuntungan ini sebelumnya juga pernah di bahas melalui penelitian serupa oleh Yanti (2015) dimana hasil serupa terkait tentang kesepakatan bersama sebagai dasar penentuan harga perolehan dan keuntungan.

\section{Harga Perolehan}

Harga perolehan adalah seluruh biaya yang dikeluarkan untuk memperoleh aset tetap tersebut mulai dari biaya pembelian hingga semua biaya yang timbul hingga aset tetap tersebut siap digunakan atau dioperasikan (Maesaroh, 2017).

Dari hasil observasi penulis menunjukkan bahwa hasil wawancara tersebut sesuai dengan kondisi yang ada dilapangan yang menjelaskan bahwa harga perolehan diterapkan sesuai kesepakatan antara BMT dan nasabah dalam memperoleh aset tetap tersebut mulai dari biaya pembelian hingga semua biaya yang timbul hingga aset tetap tersebut siap digunakan atau dioperasikan, serta kebanyakkan masyarakat/nasabah meminta harga perolehan sesuai yang disepakati dengan kedua belah pihak. Berdasarkan temuan diatas penulis berkesimpulan bahwa BMT Kota Pekanbaru menerapkan harga perolehan produk pembiayaan murabahah sesuai dengan kesepakatan bersama antara BMT dengan Nasabah seperti harga jual BMT + Margin. Akan tetapi untuk sistem harga perolehan yang didapat masyarakat masih memiliki kekurangan sehingga masyarakat/nasabah masih kurang puas dengan apa yang didapatkannya.

Oleh karena itu BMT Kota Pekanbaru harus lebih menjelaskan tentang harga perolehan yang akan didapatkan nasabah, serta BMT harus lebih memperhatiakan keinginan atau kebutuhan masyarakat/nasabah. Hasil analisis dan kesimpulan penulis menyatakan bahwa harga perolehan yang diterapakan BMT Kota Pekanbaru sesuai dengan kesepakatan bersama antara pengelolah dan pembeli. Oleh karena itu BMT tidak menentukan harga perolehan sendiri melainkan dengan kesepakatan besama, untuk menghindari timbulya riba, grarar, masyir serta harga perolehan yang didapatkan nasabah sesuai syariah islam.

\section{Uang Muka}

Uang muka adalah jumlah yang dibayar oleh pembeli kepada penjual sebagai bukti komitmen untuk membeli barang dari penjual atau pembayaran uang kepada pihak lain yang belum memberikan prestasi atau memenuhi kewajiban misalnya kepada BMT pada saat kontrak ditandatagani atau kepada penjual yang belum menyerahkan barangnya, pembayaran sebagian dan harga yang telah disepakati oleh 
pembeli dan penjual yang merupakan tanda bahwa perjajian jual beli yang diadakan mengikat.

Dari hasil observasi penulis menunjukkan bahwa hasil wawancara tersebut sesuai dengan kondisi yang ada dilapangan yang menjelaskan bahwa uang muka ditentukan sesuai permintaan nasabah/masyarakat dimana sesuai dengan barang yang dibeli dengan tata cara uang muka disetor ke rekening tabungan nasabah, nanti dipotong saat akad. Dimana uang muka adalah jumlah yang dibayar oleh pembeli kepada penjual sebagai bukti komitmen untuk membeli barang dari penjual atau pembayaran uang kepada pihak lain yang belum memberikan prestasi atau memenuhi kewajiban dengan sistem pengukuran dengan nilai wajar yang diterima nasabah sesuai dengan prinsip syariah islam.

Berdasarkan temuan diatas penulis berkesimpulan bahwa BMT Kota Pekanbaru menentukan uang muka produk pembiayaan murabahah sesuai dengan permintaan nasabah sesudah melakukan akad serta jika terjadi pembatalan pembelian barang maka pihak nasabah harus menggati rugi, dan uang muka tersebut tidak dianggap sebagai uang ganti rugi, dan uang muka yang telah di berikan nasabah kepada BMT akan di kembalikan. Akan tetapi masih ada kekurangan yang harus diperhatikan BMT kota pekanbaru agar nasabah/masyarakat lebih memilih akad murabahah dibandingkan akad lainnya. Oleh karena itu BMT Kota Pekanbaru harus lebih menjelaskan tentang uang muka yang dibayarkan nasabah kepada pihak BMT yang menjadi bukti bahwa nasabah sudah menyerahkan uang muka tersebut, untuk membeli barang dari penjual atau pembayaran uang kepada pihak lain yang belum memberikan barang atau memenuhi kewajibannya.
Hasil analisis dan kesimpulan sejalan dengan penelian sebelumnya oleh Hasanah (2015) yang juga menyatakan bahwa uang muka yang ditentukan oleh BMT sesuai permintaan nasabah saat melakukan akad bersama antara pengelolah dan pembeli. Oleh karena itu BMT tidak menentukan uang muka sendiri melainkan sesuai dengan harga barang yang dibeli.

\section{Pembelian dan Penyerahan Barang}

Pembelian merupakan kegiatan utama untuk menjamin kelancaran transaksi penjualan yang terjadi dalam suatu perusahaan atau pembelian merupakan bagian dari kegiatan ekonomi yang kita lakukan setiap hari dan penyerahan barang merupakan suatu kesepakatan antara penjual dengan peembeli tentang pemindahan hak milik disertai biaya pengiriman barang dari gudang penjual ke gudang pembeli (Suryani \& Afriyeni, 2019).

Dari hasil observasi penulis menunjukkan bahwa hasil wawancara tersebut sesuai dengan kondisi yang ada dilapangan yang menjelaskan bahwa pelaksanaan Pembelian dan Penyerahan Barang disesuaikan dengan kebutuhan nasabah dimana pembelian barang dilakukan oleh pihak BMT, barang tersebut akan diserakan kepada nasabah saat menandatagani akad tersebut. Dimana Pembelian dan Penyerahan Barang merupakan suatu kesepakatan antara penjual dengan peembeli tentang pemindahan hak milik disertai biaya pengiriman barang dari gudang penjual ke gudang pembeli. Berdasarkan temuan diatas penulis berkesimpulan bahwa BMT Kota Pekanbaru menerapkan Pembelian dan Penyerahan Barang produk pembiayaan murabahah sesuai dengan permintaan nasabah sesudah melakukan akad setelah itu pihak BMT menyerahkan barang tersebut kepada nasabah. 
Akan tetapi dalam pembelian dan penyerahan barang masih ada terdapat kekurangan yang harus diperhatikan BMT kota pekanbaru agar nasabah/masyarakat lebih memahami akad murabahah dengan prinsip syariah islam. Oleh karena itu BMT Kota Pekanbaru harus lebih menjelaskan tentang pembelian dan penyerahan barang yang dilakukan pihak BMT kepada nasabah yang sudah menandatangani akad murabahah, supaya tidak terjadi kesalahan yang menimbulkan keraguan nasabah kepada pihak BMT. Hasil analisis dan kesimpulan ini sejalan dengan penelitian Suryani \& Afriyenti (2019) bahwa pembelian dan penyerahan barang yang ditentukan BMT sesuai permintaan nasabah saat melakukan akad bersama antara pengelolah dan pembeli. Oleh karena itu BMT tidak menentukan pembelian dan penyerahan barang sendiri melainkan sesuai dengan perjanjian yang sudah disepakati dimana barang diserahkan pada saat akad murabahah ditandatagani oleh pihak nasabah.

\section{Pembayaran Tangguh}

Pembayaran tangguh adalah pembayaran yang dilakukan tidak pada saat barang diserahkan kepada pembeli tetapi pembayaran dilakukan dalam bentuk angsuran atau sekaligus pada waktu tertentu (Haryoso, 2017).

Dari hasil observasi penulis menunjukkan bahwa hasil wawancara tersebut sesuai dengan kondisi yang ada dilapangan yang menjelaskan bahwa Pembayaran Tangguh tidak diterapkan oleh BMT kota pekanbaru serta pembayaran tangguh hanya dilakukan nasabah saat terlambat membayar angsuran kepada pihak BMT. Dimana Pembayaran tangguh adalah pembayaran yang dilakukan tidak pada saat barang diserahkan kepada pembeli tetapi pembayaran dilakukan dalam bentuk angsuran atau sekaligus pada waktu tertentu. Berdasarkan temuan diatas penulis berkesimpulan bahwa BMT Kota Pekanbaru tidak menerapkan pembayaran tangguh untuk produk pembiayaan murabahah melainkan nasabah terlambat membayar angsuran yang sudah ditentukan batas waktu pembayaran.

Akan tetapi dalam meningkatkan ketertarikan nasabah/masyarakat dalam memilih akad murabahah maka BMT harus memberikan keringanan kepada nasabah untuk melunasi angsuran yang belum dibayar nasabah kepada BMT sehingga nasabah/masyarakat percaya kepada BMT untuk mempermudah dalam memenuhi kebutuhan nasabah/masyarakat. Oleh karena itu BMT Kota Pekanbaru harus lebih menjelaskan tentang pembayaran tangguh yang dilakukan nasabah supaya membayar angsuran sesuai dengan waktu yang disepakati di awal pas akad dilaksanakan dan tidak melakukan pembayaran tangguh lagi kepada BMT agar dapat meningkatkan kepercayaan BMT kepada nasabah/masyarakat dalam memenuhi kebutuhannya. Hasil analisis dan kesimpulan penelitian ini sejalan dengan penelitian oleh Hadaliah (2018) dimana menyatakan bahwa ratarata BMT tidak ada yang menerapkan pembayaran tangguh. Tetapi ada sebagian nasabah tidak membayar angsuran sesuai dengan waktu yang telah di tentukan. Maka BMT harus tegas dalam mengambil keputusan yang terbaik dalam meningkatkan usaha serta membantu nasabah untuk memenuhi semua kebutuhannya.

\section{PENUTUP \\ Kesimpulan}

Berdasarkan hasil penelitian yang sudah penulis lakukan dapat disimpulkan bahwa Impelementasi 
Produk Pembiayaan Murabahah yang dilakukan pada Baitul Mal Wat Tamwil Kota Pekanbaru dapat dilihat dari beberapa dimensi dalam penelitian ini yang dijabarkan sebagai berikut; produk pembiayaan murabahah BMT kota pekanbaru yang menerapakan obyek produk pembiayaan murabahah yang ditawarkan BMT Kota Pekanbaru sangat diminati masyarakat karna tidak ada unsur ribanya dan tidaklah bertentangan dengan hukum dalam syariat islam.

Keuntungan yang diterapakan BMT Kota Pekanbaru sesuai dengan kesepakatan bersama antara pengelolah dan pembeli. Oleh karena itu BMT tidak menentukan harga perolehan dan keuntugan sendiri melainkan dengan kesepakatan besama, untuk menghindari timbulya riba. Harga perolehan yang diterapakan BMT Kota Pekanbaru sesuai dengan kesepakatan bersama antara pengelolah dan pembeli. Oleh karena itu BMT tidak menentukan harga perolehan sendiri melainkan dengan kesepakatan besama, untuk menghindari timbulya riba, grarar, masyir serta harga perolehan yang didapatkan nasabah sesuai syariah islam. Selanjutnya uang muka yang ditentukan BMT Kota Pekanbaru sesuai permintaan nasabah saat melakukan akad murabahah antara pengelolah dan pembeli.

Oleh karena itu BMT tidak menentukan uang muka sendiri melainkan sesuai dengan harga barang yang dibeli. Pembelian dan penyerahan barang yang diterapkan BMT Kota Pekanbaru sesuai permintaan nasabah saat melakukan akad bersama antara pengelolah dan pembeli. Oleh karena itu BMT tidak menentukan pembelian dan penyerahan barang sendiri melainkan sesuai dengan perjanjian yang sudah disepakati dimana barang diserahkan pada saat akad murabahah ditandatangani oleh pihak nasabah. Semua BMT kota pekanbaru tidak ada yang menerapkan pembayaran tangguh. Tetapi ada sebagian nasabah yang melakukan pembayaran tangguh dikarenakan tidak membayar angsuran sesuai dengan waktu yang telah di tentukan.

\section{Saran}

Melalui hasil penelitian ini maka dapat di sarankan kepada seluruh BMT di Kota Pekanbaru untuk tegas dalam mengambil keputusan yang terbaik dalam meningkatkan usaha serta membantu nasabah untuk memenuhi semua kebutuhannya. Juga bagi peneliti selanjutnya untuk melakukan pengujian secara kuantitatif terkait dengan masalah pembiayaan yang di tawarkan oleh BMT.

\section{DAFTAR PUSTAKA}

Azizah, N. (2015). Implementasi 5C pada pembiayaan murabahah di KJKS BMT El Amanah Kendal (Doctoral dissertation, UIN Walisongo).

Affandi, A. A. (2015). Analisis pembiayaan murabahah pada nasabah di BMT Harapan Ummat Kudus (Doctoral dissertation, UIN Walisongo).

Febrian, R., \& Mardian, S. (2017). Penerapan PSAK NO. 102 Atas Transaksi Murabahah: Studi Pada Baitul Maal Wa Tamwil Di Depok, Jawa Barat. Ikonomika, 2(1), 19-40.

Hadaliah, L. D. (2018). Aplikasi Akad Murabahah Pada Poruduk Konsumtif. MUTAWASITH, 1(1) , 35-52.

Hasanah, N., Puspitasari, N., \& Farida, L. (2015). Risiko Akad Murabahah Serta Pengelolaan Risiko Akad Murabahah Pada BMT-UGT Sidogiri Cabang 
Wongsorejo,

Kabupaten

Banyuwangi. E-Journal

Ekonomi Bisnis dan

Akuntansi, 2(1), 1-5.

Haryoso, L. (2017). Penerapan Prinsip

Pembiayaan

Syariah

(Murabahah) pada BMT Bina

Usaha di Kabupaten

Semarang. Law and

Justice, 2(1), 79-89.

Iltiham, M. F. (2017). Implikasi Akad Simpan Pinjam dalam Perspektif Hukum Kontrak Fiqih (Studi Pada BMT-MMU Pasuruan Cabang Purwosari). MALIA (TERAKREDITASI), 9(1), 83100.

Maesaroh, N. S. (2017). Implemetasi ganti rugi terhadap keterlambatan pembayaran pada produk pembiayaan murabahah di BMT Nurul Ummah Sukabumi (Doctoral dissertation, UIN Sunan Gunung Djati Bandung).

Sagara, Y., \& Pratama, M. A. (2016). Penguatan Ekonomi Kerakyatan
Melalui Baitul Mal Tanwil (BMT) Sebagai Balai Usaha Mandiri Rakyat Terpadu (BUMRT). Social Science Education Journal, 3(1).

Suryani, A., \& Afriyeni, A. (2019). Prosedur Pemberian Pembiayaan Murabahah Pada Baitul Mal Wat Tamwil (Bmt) Taqwa Muhammadiyah Padang.

Tamrin, M. A., \& Suselo, D. (2017). Implementasi Akad Murabahah dalam Penentuan Harga dan Margin Pembiayaan pada BMT di Tulungagung. Jurnal Iqtisaduna, 4(1), 12-29.

Yanti, U. R. (2015). Analisis FaktorFaktor Yang Mempengaruhi Keputusan Nasabah Untuk Mendapatkan Pembiayaan Murabahah Di Bmt Al Hijrah Salo Kabupaten Kampar (Doctoral dissertation, Universitas Islam Negeri Sultan Syarif Kasim Riau) 